\title{
Frode Ulvund
}

Fridomens grenser 1814-1851. Handhevinga av den norske "jodeparagrafen". Oslo: Scandinavian Academic Press, 2014, 378 s. NKr 399.-

Forbuddet mod jøder, jesuitter og munkeordener i $\$ 2$ i den norske grundlov af 1814 har i 200 året for loven været genstand for flere bøger, foredrag og debatter. Med få måneders mellemrum traf man i Danmark og i Norge helt forskellige bestemmelser om jøders fremtidige stilling i de respektive lande. Medens man i Danmark udstedte det såkaldte jødiske "Frihedsbrev", den kgl. anordning af 29/3 1814, som stillede jødiske borgere lige med alle andre borgere mht. erhvervsudøvelse, gik man den modsatte vej i Norge og forbød jøder adgang til riget, idet der stod, at de fremdeles skulle være udelukket. Hvorfor? Og hvorledes praktiserede man i Norge denne bestemmelse? Det har været forfatterens mål at undersøge i denne bog.

Behandlingen af det spørgsmål, hvorledes man håndhævede denne paragraf, begynder dog først halvvejs inde i bogen (s. 141), for forf. opridser inden dette jødernes stilling i Norge før 1814. Han maner den opfattelse i jorden, som man af og til kan høre, at der ikke var jøder i landet før den tid. Som eksempel nævner han bl.a. Salomon Simon, men kender åbenbart ikke beskrivelsen af hans senere skæbne, ligesom han heller ikke nævner andre proselytter, som er omtalt i nyere tid (Thamar Wallich og Isaach Abraham Cohn). I denne forbindelse savner man også i afsnittet Konverterte jødar $i$ Danmark-Norge (123-126) henvisning til de 121 jødiske proselytansøgere i pietismens tid og til de $120 \mathrm{i}$ årene 1760-1814, som er meddelt i mine bøger fra 2002 og 2002, i stedet for forf.'s henvisning til Weitemeyers ufuldstændige meddelelser (1919). Videre oplyser forf. om Moses Mendelsohns oplysningsbevægelse, om det danske frihedsbrev og de samtidige forhold i Sverige. Han stiller også det spørgsmål, hvorfor det nævnte forbud overhovedet kunne gennemføres og nævner især præsterne Nicolaj Wergelands, Hans Grøgaards og andres aktiviteter for forbuddet og de tre præster og et par andre, som var imod. Man bemærker her forf.'s vigtige iagttagelse om kildeproblemerne (s. 88), om de samtidige tolkninger af ordet fremdeles (92) og hans konklusion, at motiverne for forbuddet var både politiske, merkantilistiske og religiøse (98-149). Hertil kan føjes, at de sædvanlige fordomme florerede lystigt blandt debattørerne.

Bogen har til gengæld sin styrke i kapitlerne 5 til 11, hvor forf. arbejder på grundlag af utrykte kilder som bl.a. Bergens politimesters og stiftamtmandens arkiv, Bergen magistrats arkiv, Kristiania stiftamt, kirkers arkivalier og andet. Ejendommeligt nok har forf. ikke lavet en samlet fortegnelse over disse arkivalier, bortset fra, at henvisninger nævnes i noterne. På grundlag af disse kilder kan forf. nemlig direkte vise, hvor strengt man med forhør og udvisninger efterlevede $\$ 2$ i de første år. Rygter spillede en vigtig rolle, blot mistanken om at være jøde var nok til udvisning. Han undersøger her forholdene mellem lokale og de centrale myndigheder. Han viser også, hvor- 
ledes man med tiden gik mere og mere lempeligt frem, udstedte lejdebreve både til enkeltpersoner og grupper og lod en mand som Joseph Hambro rejse frit ind og ud af landet. Han forstrakte staten med et større lån. Disse kapitler er meget vigtige supplementer til de hidtidige undersøgelser af den berygtede $\$ 2$. Forf. viser endelig, hvorledes denne liberalisering af praksis åbnede vejen for jødeparagraffens ophævelse i 1851, uanset at der endnu i 1849 var en stor gruppe politikere, som ville bevare den. Bortset fra de påpegede mangler og fejl i formalia - visse personnavne staves temmelig forkert - udgør bogen et meget vigtigt bidrag til analyserne af motiverne til jødeparagraffens vedtagelse og til håndhævningen af den indtil afskaffelsen.

Martin Schwarz Lausten

\section{Geert Hallbäck \& Troels Engberg-Pedersen}

Det første evangelium. En samtale om Markusevangeliet. København: Forlaget Anis 2014. 285 s. Kr. 249.

Denne nye bog om Mark. er blevet til på opfordring og initiativ af Troels Engberg-Pedersen. Hovedforfatteren er Geert Hallbäck. De to nytestamentlige fagfæller mødtes ca. en gang om ugen i 2012, og TE-P nedskrev så, hvad der var kommet på bånd og i kladde, renskrev det hele og gjorde det klart til forlaget. Det er der kommet en helt ny litterær genre ud af: en kommentar til et bibelsk skrift i let forståeligt, ofte meget direkte og dagligdags sprog, hvor de to forfatteres opfattelser gang på gang brydes, men enighed om det væsentligste som regel opnås til sidst. Den nye kommentar-genre, som anmelderen ikke husker at have set før, stiller overvældende krav til forfatterne. I det foreliggende tilfælde er kravene til fulde blevet opfyldt.

Efter et kort forord, hvori der redegøres for bogens tilblivelse, gås der lige og direkte på med selve Mark., hvis 16 kapitler vies 16 kompakte samtaler (side 11-249) med udblik til skriftets disposition, til enkelt-emner i ekskursform, fx om templet i Jerusalem og om apokalyptik. Til sidst kommer der en "udledning" (side 251-272) om Markusevangeliet som helhed, som måske er lidt skuffende, da læseren gennem de 16 kapitler allerede er blevet belært om, hvordan de to forfattere ser på de traditionelt såkaldte "indlednings-spørgsmål”. Heldigvis daterer forfatterne ikke Mark. til "omkring” år 70 (Jerusalems fald og templets ødelæggelse), så man ikke véd, om det er før eller efter, men til kort efter år 70 (se især side 188-189). Skriftet har været kendt og brugt af Matt. og af Luk. og muligvis også af Joh. Mark.s narrative og kompositoriske indsats, som var formidabel, fremhæves med rette. Bogen afsluttes med en litteraturliste og et navne- og sagregister (side 273-285).

To temaer er særligt vigtige, ja, uomgængelige for både GH og TE-P. Det ene er spørgsmålet om, hvilken Jesus det er, som Mark. skildrer: Er det den jordiske Jesus eller den historiske Jesus? GH hævder, at det er den jordiske, og vil overhovedet ikke udtale sig om den historiske Jesus, fordi vi ikke kan, 